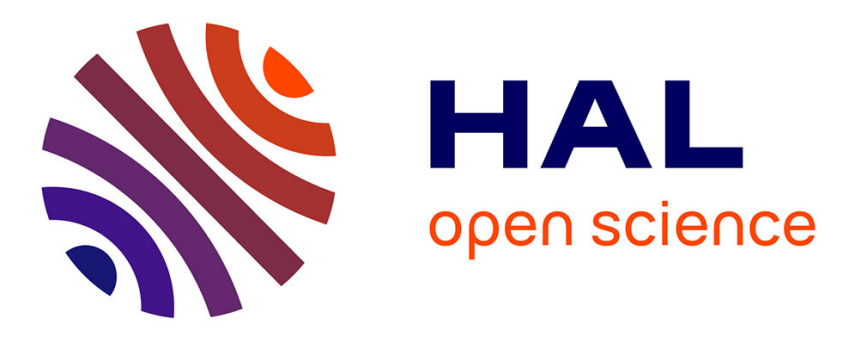

\title{
"What Difference Does it Make?" Studying Urban Popular Music from Before the Generalization of the Gramophone: the Example of the First World War Repertoire
}

\author{
John Mullen
}

\section{To cite this version:}

John Mullen. "What Difference Does it Make?" Studying Urban Popular Music from Before the Generalization of the Gramophone: the Example of the First World War Repertoire. Julia Merrill (Ed.) Popular Music Studies Today, Systematische Musikwissenschaft, 2017. hal-02453458

HAL Id: hal-02453458

https://hal-normandie-univ.archives-ouvertes.fr/hal-02453458

Submitted on 16 Feb 2020

HAL is a multi-disciplinary open access archive for the deposit and dissemination of scientific research documents, whether they are published or not. The documents may come from teaching and research institutions in France or abroad, or from public or private research centers.
L'archive ouverte pluridisciplinaire HAL, est destinée au dépôt et à la diffusion de documents scientifiques de niveau recherche, publiés ou non, émanant des établissements d'enseignement et de recherche français ou étrangers, des laboratoires publics ou privés. 


\title{
"What difference does it make?" Studying urban popular music from before the generalization of the gramophone: the example of the First World war repertoire.
}

\author{
John Mullen, Université de Rouen Normandie, Research \\ team ERIAC
}

For the last ten years I have been working on popular song, mostly in Britain, between 1880 and 1918, and often concentrating on the songs and the music hall industry of the First World War. ${ }^{1}$ Taking up this work, I found it to be wedged between two different traditions. There existed a number of analytical books on the Victorian music hall ${ }^{2}$, but very few on the twentieth century, and on the other hand there was a tremendous amount of work being done on popular music produced after 1950, rock music and later forms.

One of my objectives was to explore to what extent the work on the Victorian age had produced conclusions which could still be applied to the repertoires and processes of the early twentieth century, and, moving in the other direction, what analyses and perspectives on late twentieth century and early twenty first century popular

\footnotetext{
${ }^{1}$ See for example John Mullen The Show Must Go On : Popular Song in Britain during the First World War, Ashgate, Farnham, 2015 ;

"Patriotic Palaces of Pleasure? The Music Industry in Britain in 1900", Civilisations $\mathrm{N}^{\circ} 13,2014$; "Anti-Black Racism in British Popular Music 1880-1920" Revue française de civlisation britannique XVII-2, 2012 ; "Velours rouge et piquets de grève - la grève du music-hall à Londres en 1907" Cahiers victoriens et édouardiens, 67, avril 2008.

${ }^{2}$ For example, Peter Bailey, (Ed.). Music-hall, the Business of Pleasure. Milton Keynes: Open University Press, 1986; ----------, Leisure and Class in Victorian England: Rational Recreation and the Contest for Control, 18301885, London: Methuen, 1987. ----------, Popular Culture and Performance in the Victorian City. Cambridge: Cambridge University Press, 1998; J.S. Bratton, (Ed.). Music Hall: Performance \& Style. Milton Keynes: Open University Press, 1986; Paul Maloney, Scotland and the Music Hall, 1850-1914. Manchester: Manchester University Press, 2003.
} 
music might already apply to the products and industries of a century ago.

Working specifically on the Popular song of the first world war, I also had to fit my work in with the field of First World War history. This could be delicate. Like other researchers in Popular music, I had to justify my object of study: in a period of total war, in which deaths and injuries were counted in millions, it might be considered trivial to study products of entertainment. Such pressure was reinforced by the sacralization and the politicization of Great War memory in a number of countries, and particularly in Britain, where the centenary commemorations have been the occasion for a full-scale political debate. ${ }^{3}$ The study of popular song in order to help understand the worries, fantasies and priorities of ordinary people might it not threaten an established national narrative of unquestioning mass jingoism?

In this No-man's land between First World War history and Popular Music Studies, two questions in particular seemed important to me

Firstly, what was the specificity of a popular song as an object of historical study: what difference did it make that one was studying a song rather than another object or process? And secondly what was the specificity of songs from a century ago as objects of Popular Music studies: what difference does it make that these songs were hits before the generalization of the gramophone? ${ }^{4}$

\footnotetext{
${ }^{3}$ John Mullen, "Experiences and Contradictions: How the British Celebrated the Centenary of 1914", Revue française de civilisation britannique, XXI-1, 2015.

${ }^{4}$ Many readers will be unfamiliar with the songs I am speaking of. These three available on Youtube can serve to give a very general idea of the sounds involved : Marie Lloyd's "A Little of What You Fancy Does You Good" https://www.youtube.com/watch?v=X6P zU5oxF8 ; "Goodbyee" by Courtland and Jeffries https://www.youtube.com/watch?v=jVavtX80m3Q ; "Keep the Home Fires Burning” John McCormack https://www.youtube.com/watch?v=5P8UokgVqWs
} 


\section{First World War History}

To deal with the first of these questions, I first need to explain a little about the historiography of the First World War, a subject which has produced tens of thousands of books. Jay Winter and Antoine Prost in their book ${ }^{5}$, describe the historiography of the war as being marked by three main types of history, each dominating by turn academic and publishing interest. Firstly, military and diplomatic history ruled the roost for thirty years after 1918. Secondly, in the post-war boom, social history rose to influence, finally, from the 1980 s on, cultural history (somewhat more difficult to define) was the key player.

The types of history can mostly be distinguished by the kinds of questions they considered were a priority. Diplomatic and military history was in its early decades very much "history from above". Its key questions turned around leadership strategies of governments and general and how they might have been improved. The questions of how the war was won, and who was to blame for the outbreak of the war, were much explored. The aim of justifying policy was often present. There was little interest in ordinary people or ordinary soldiers. The lived experience on the ground was simply not considered to be a suitable subject of historical study, to such an extent that the great French historian, Pierre Renouvin, seriously wounded in the war, never mentions his own experience in his historical works.

Later military history, and there continue to be over a hundred books of military history of the First World War published every year, put, on the contrary, much emphasis on the lived experience of the individual soldier, nurse,

There is a wider selection here : http://www.firstworldwar.com/audio/1915.htm

${ }^{5}$ The Great War in History: Debates and Controversies, 1914 to the Present, Cambridge, Cambridge Univeristy Press, 2005. 
priest, machine gunner, officer, prisoner of war etc. This is the type of book which far outsells any other sort.

After the Second World War, the multiplication in the number of universities, the further progress of the democratic spirit in society, the decline of deference, the possibility given to some working-class youngsters to become historians and the growing influence of Marxism in university circles led to the rise of social history. New questions were asked about the war, questions about the transformation of social structures, the changes in women's lives, the effect on civilians. Books would be published about women munition workers or footballers, about the life of political parties, voluntary organizations or churches.

Finally, twenty years later, the third type of history will come to dominate First World War studies. This is cultural history. Vast (indeed the number of historians was still growing rapidly) and difficult to define precisely, cultural history shared with social history an interest for the ordinary folk. Its rise to pre-eminence reflected a reduction in the influence in Marxism in academic circles, concomitant with the collapse of the Soviet bloc, but also a rise in interdisciplinary approaches which borrowed from many other scholars who were not historians (cultural studies people, literary analysts and the like).

Cultural history's strongest point was no doubt its capacity to massively extend the range of what could be considered as an object of historical study. Its weakest point was a tendency to minimize the role of the state and of collective organization in the course of history and the forging of individual consciousness.

The study of the constitution and uses of collective memory make up a considerable part of cultural history concerning the First World War, and more generally, the history of representations has been on the rise. 
The rules of studying cultural production

But also within cultural history we find the study of cultural expression in wartime, be it theatre, literature, postcards, war monuments, soldiers letters, letters to the press etc. And, fortunately for my career, ten years ago, no one had seriously studied the history of British popular song in the First World War.

Studies of these cultural expressions have some characteristics in common. They concern themselves with what might be called the grammar of their objects of study. For example, the studies of the thousands of commemorative monuments to the war dead needed to know who financed the building of the monuments, who made the key decisions, and so on. Researchers found, for example, that families of dead or wounded had little say in the decisions about the content of monuments: local elites took over these policy decisions. The researchers went on to analyse the repertoire of visual symbols, texts, ceremonies etc., used for the establishment of the monuments.

To take another example, those who studied postcards produced during the war on war themes (often comic or sentimental) collected information about the situation and priorities of the producers (general very small businesses). The closeness of the producers to their customers meant that the images they felt would sell reflected the opinions, worries and fantasies of the millions of ordinary people who bought them.

\section{Is it the same for songs?}

It would seem, then, that there are many points in common between these studies of means of cultural expression and the study of commercial wartime songs. These songs had a similar need to follow closely developments in fantasies, anxieties and opinions of their mass audience, at the same 
time as avoiding repeating excessively previous productions.

To understand the song repertoires and the music industry processes of the First World War it was necessary to identify the different actors (theatre chains, touring artistes, publishing companies, freelance lyricists), the legal and economic framework (no royalties for lyricists, legal dangers attached to 'vulgar' songs), traditional and newer forms of musical spectacle and their constraints (music hall, revue, pantomime, musical comedy), ideological parameters (patriotism, respectability or expression of working class identity) and so on.

An important difference concerning the study of song resided no doubt in the tremendous amount of emotion and identity tied up with musical repertoires. Whether it be in 1916 or 2016, there are few people who are as attached to monuments or postcards as they are to their favourite songs and performances of songs.

Popular Music Studies and the First World War repertoire

Coming at the same question - "What difference does it make?" from the contrary point of view, I will now evaluate what methods and approaches current in Popular Music Studies today can be fruitfully applied to the First World War repertoires and processes. Bennet, Shank and Toynbee's influential Popular Music Studies Reader helpfully divides the field into the following nine sections.

- Music as sound, music as text

- Making music

- Subculture scenes and tribes

- Popular music and everyday life

- Musical diasporas

- Music industry

- Popular music and technology

- Popular music media 
- Popular music, gender and sexuality

How can each of these apply to the music a hundred years ago? There is not space in this paper to discuss all of them, but let us explore some.

\section{Musical material and the music industry}

Certainly, the music can be analysed as sound and text. For the texts, if the British wartime repertoire is generally not complex (partly because lyricists sold songs for a small one-off payment and didn't receive royalties), that of some other countries such as France is sophisticated in theme and lyric, exploring a wide variety of problems and dreams of wartime experience (infidelity, disfigurement, hatred of the enemy, national morality etc.) And any repertoire, including the British, can be studied for its ideological implications (hits included a few racist and anti-Semitic songs, many songs about respectability and dozens expressing worry about how women's roles had changed, for example).

The music of the British repertoire cannot be innovative. The artiste is generally on tour and the local house orchestra must learn, on Monday morning, the artiste's songs for the first performance Monday evening. Innovative or difficult music would likely result in an artiste not being hired. In addition, there was of course no studio work to analyse as there is today. The low level of musical control and musical ambition would make it difficult to carry out analyses of the sort Susan Fast did on Led Zeppelin's classic hit. Some elements of musicological analysis proper have nevertheless supplemented political and social analyses of First World War songs in some publications. ${ }^{6}$ Such analyses are not without their difficulties, in that the technical language of music

\footnotetext{
${ }^{6}$ See in particular Christina Gier Singing Soldiering and Sheet Music in America during the First World War, Lexington, 2016.
} 
is not generally available to readerships of First World War history books, be they academic of wider. Since the historian, in addition to being a researcher, is also a storyteller, this can be problematic.

There was one element of sound content, the most intimate element, over which the artiste retained much control: the voice. I have been researching on the use of voice in the music-hall. The lack of microphones in a hall of two or three thousand seats obviously limited the repertoire of voices that could be employed. The choice of voice tended to be made on a theatrical rather than a technical basis, to project a character the audience can love or laugh at or both. The choice of a voice slightly the worse for drink, ${ }^{7}$ a voice of operetta, ${ }^{8}$ a cockney working class voice, ${ }^{9}$ or a gendered voice ${ }^{10}$ (for the many cross-dressing artistes) allows the study of the ideological and social underpinnings of these choices.

\footnotetext{
${ }^{7}$ Sam Mayo, «Bread and Marmalade » https://www.youtube.com/watch?v=6o 5 FogG2Vk

${ }^{8}$ Gertie Gitana « My Dear Marie » https://www.youtube.com/watch?v=pnF6CnaHlcI

${ }^{9}$ Gus Elen "Wait till the Work comes round" https://www.youtube.com/watch?v=MO1E9GUs9Ak ${ }^{10}$ Vesta Tilley "Bit of a Blighty One" https://www.youtube.com/watch?v=8WVE9OHxKsA
} 
Music-making as an industry is certainly a very fruitful domain to examine a hundred years ago. The industry was being transformed in Britain at this time by the concentration of capital, which led to the domination of chains of theatres which could maintain profits by making economies of scale, and by signing exclusive contracts with the bigger stars, denying access to talent for independent local theatres. These chains were quoted on the Stock Exchange and could pay out hefty dividends to their shareholders. Many local theatres went bankrupt or were bullied into joining the chains. Regular crises of overproduction occurred in the industry as local markets for shows were flooded by newly opened theatres, before some went bankrupt or were converted into cinemas.

Pre-industrial traditions, based on the exchange of goodwill and gifts, were slowly disappearing, but the position of the music hall owner or manager as someone only recently accepted in local elites ensured the continuance of some of these traditions (free use of the theatre for charity shows was almost obligatory, for example). The rise of trade unionism, in particular after the music hall strike of 1907 in London, had very much influenced the industry, establishing minimum wage rated for orchestra players, and an arbitration board in collaboration with the government to mediate in industrial disputes. The union journal The Performer allows the researcher a privileged insider's view. ${ }^{11}$ The Music-hall artistes' trade union, the Variety Artistes Federation, considered itself very much part of the wider trade union movement, and its paper carried for many years on its front page the motto "the greatest enemy to freedom is not the tyrant, but the contented slave".

\footnotetext{
${ }^{11}$ See John Mullen, "Red Plush and Picket Lines: Music-Hall Trade Unionism 1906-1920" in Rosemary Golding (Ed), The Music Profession in Britain 1780-1920, London, Routledge, forthcoming
} 
One of the most interesting areas to research is to try to tease out the links between economic developments in the industry and artistic content, which mutually influence each other. The rise of the revue, a single all-evening show, threatened, after 1911, the older music hall evening made up of individual and constantly changing turns. The revue benefitted from economies of scale and made it possible to hire dancing troupes and other new groups of skilled workers. The revue could then tour nationally or even internationally as a unit. The revue was a result of the concentration of capital, and it integrated many music hall stars and content. But it also transformed the content. Centralized artistic control allowed more considered experimentation with the building up of atmosphere, for example, which had been all but impossible for the music hall singer who had his or her fifteen minutes after the elephant act and before the acrobats. One of the results was the huge rise in romantic content in the revue compared with the music hall.

\section{Questions of identity}

A priori much less productive for our period is the approach based on "Subculture, scenes and tribes". The teenage market did not and could not exist, leisure time and education were very much less developed. The choice of music for working class people often boiled down to going to the music-hall, attending the cheap classical concerts at the town hall, or being satisfied with listening to street singers or sitting at home "When Uncle sings the only song he knows" 12 . The popular music market was far less segmented than today: twelve year olds and sixty year olds went to the same shows. And the infrastructure and leisure time for fan clubs, fanzines, or Facebook groups around musical tastes was not available.

${ }^{12}$ The title of a 1904 music-hall song. 
Nevertheless, the use of musical production to express and reinforce identities is well worth looking at a century ago. At the time, it was mostly a question of class identities. The music hall stars sang in theatres whose furnishing imitated the homes of the bourgeoisie, but, for the most part, sang in working class accents about everyday working class life. Numerous songs and practice try to situate working class identity in relation to such ideological parameters as respectability or vulgarity. Other identities counted too: attitudes to the colonized Other in the racist songs of the music-hall deserve study, as do the contradictory attitudes to Irishness in the repertoire.

As for the domain of "popular music, gender and sexuality", gender identities are already omnipresent. Many dozens of songs of the British wartime repertoire express anxiety concerning the changing roles of women. The songs do not usually either denounce or celebrate the new roles, but express ambiguous attitudes: it's wonderful and dangerous, a point of view which was certainly very prevalent among both women and men at the time. The French wartime repertoire is characterized by an exploration - often through melodrama- of fears around gender roles and couple relationships. Songs about the soldier who receives a letter discovering his wife is unfaithful, about the soldier returning on leave after twelve months to find a baby in the house, about women replacing men as head of the household after the war, or about the worries of a disfigured soldier about the loyalty of his fiancée, are typical examples. ${ }^{13}$

"Popular music media" and "technology and popular music" are two themes which would be much less fruitful for the historical research we are dealing with. Critical discourse about popular music was very little developed. Specialized magazines such as Phono Record contain

\footnotetext{
${ }^{13}$ Anne Simon, Chanter la Grande Guerre: les Poilus et les Femmes, Paris, Champ Vallon, 2014.
} 
fascinating anecdotes such as the shock people at a funeral experienced on finding that the deceased had recorded himself singing a hymn to be played at his own funeral, but they were mostly about the industry or about technical questions. Reviews of shows in the national or local press tended to be uniformly positive, and the expert audience required to sell sophisticated critiques of popular music did not exist.

\section{What difference does it make?}

What, then, is different about working on songs from a century ago. Firstly, the repertoire, though large, is smaller: one can more easily construct a representative corpus of five hundred songs from 1916 than from 2016.

Secondly, there is the question of archives. When one works, as I am doing at the moment, on the 1970s, the problem is that there is far too much archival material, recordings, videos, people to interview, press coverage and so on. For the 1900s, much has been lost. In some countries, like France, the existence at the time of an official censorship of songs, whose offices kept a copy of every song examined as well as the decision taken, make life easy for the historian. In other countries, most of the repertoire has disappeared forever, or can only be reconstituted by having access to plenty of time and money. The British case is intermediate: there are 1200 songs from the war years in the British Library and at least 300 recordings of songs are available. Nevertheless, many British songs have been lost.

This brief paper has, I hope, clarified some of the main issues in historical popular music studies. In conclusion, I would like to open up the question of comparative work. What would be the usefulness of a comparative study of the top twenty most popular songs from 1918 and from 
2018 in a given country? It might shed light on what is relatively permanent (the three-minute song, the singalong chorus, the role of virtuosity, the centrality of the transgressive) and what is ephemeral in this mass activity which interests us so much.

John Mullen

John Mullen is Professor of British Studies at the University of Rouen in France. He has written widely on the history of British popular music: on music hall, on music festivals and on rock and politics. His book The Show Must Go On: Popular Song in Britain during the First World War was published in the Ashgate Popular and Folk Music series in 2015. 